\title{
Orius albidipennis (Rueter) as an effective biocontrol agent against Tetranychus urticae Koch on pepper crops in greenhouse in Egypt
}

\author{
S. A. El Arnaouty ${ }^{1}$, Mona N. Kortam² ${ }^{2 *}$ Amal I. Afifi ${ }^{1}$ and I. H. Heikal ${ }^{2}$
}

\begin{abstract}
The present study was carried out in greenhouses, on sweet pepper crops, during the winter plantations 2015-2016 and 2016-2017 in a commercial farm located at Berkash district, Giza, Egypt. During the first season, three acariphagous biocontrol agent species, the predatory mite, Amblyseius swirskii Athias-Henriot (Acari: Phytoseiidae) (at a rate of 2 individuals $/ \mathrm{m}^{2}$ ), and two of predatory insect, Macrolophus caliginosus Wagner (at a rate of 1 individual $/ \mathrm{m}^{2}$ ) and Orius albidipennis (Reuter) (at a rate of $1 / 2$ individual adults $/ \mathrm{m}^{2}$ ), were applied to control Tetranychus urticae. The obtained results showed that $T$. urticae was controlled successfully using A. swirskii and O. albidipennis. Releasing of A. swirskii and O. albidipennis caused 26 and $24 \%$ yield increases, respectively, as compared to control treatment. During the second season of 2016-2017, the efficiency of 0 . albidipennis at a rate of $1 / 2$ per $\mathrm{m}^{2}$ was compared to three recommended pesticides, for controlling T. urticae. The obtained results revealed that applying $O$. albidipennis proved to be the most efficient control method against T. urticae on sweet pepper, with the lowest remaining pest density of T. urticae (2.9 mites/leaf); while with chemical control, the remaining density of $T$. urticae reached 20.13 mites/leaf at the end of the season. Thus, results demonstrated that the released insect predator, 0 . albidipennis, was the most effective method to control T. urticae under greenhouse conditions for two reasons. On the one hand, it resulted in a $31.36 \%$ yield increase, and on the other hand, it could reduce the chemical application, to improve food safety and environmental pollution reduction.
\end{abstract}

Keywords: Biological control, Chemical control, Spider mites, Amblyseius swirskii, Macrolophus caliginosus, Orius albidipennis

\section{Background}

The sweet pepper, Capsicum annuum L., is one of the most important vegetable crops. In Egypt, it is cultivated for local consumption and exportation (El-Laithy et al. 2013). It covers a production area of about a quarter million $\mathrm{m}^{2}$ in greenhouses and yielded 9993 tons in 2013 (Heikal and Ebrahim 2013). The two spotted spider mite, Tetranychus urticae Koch, is a ubiquitous and economically important agricultural pest feeding on a wide range of host plant species (Xie et al. 2006). Probably, the most important pest species in the family is Tetranychidae (Tehri et al. 2014) and it is known to

\footnotetext{
* Correspondence: sweetdays13@yahoo.com

${ }^{2}$ Central Laboratory of Organic Agriculture, Agric. Res. Center, Giza, Egypt Full list of author information is available at the end of the article
}

attack about 1200 species of plants. The economic threshold for spider mites was estimated as three or more motile forms per leaf (Warabieda 2015). Under favorable conditions, spider mites can rapidly build up to very large populations where they are characterized by a high reproductive capacity, causing important economic damage and yield losses close to 90\% (Ginette et al. 2014).

Chemical control is the most common strategy for controlling T. urticae. However, this strategy is hindered by the development of population resistance to acaricides. Moreover, pesticide residues build up in leaves. Thus, the option of applying biological control against $T$. urticae has been considered, since it is a way to solve the prior mentioned problems. Among 
the natural enemies of $T$. urticae, Orius spp. have shown promising control capacities and thus interest for their use as one of the biological control agents. Orius albidipennis is the commonest Orius species in Mediterranean countries (Al-Kherb 2013), which led us to choose it in the present study.

Amblyseius swirskii Athias-Henriot is one of the most important generalist indigenous predators of tetranychid mites (Fatnassi et al. 2015). This mite is a polyphagous predator capable of preying on a number of food items, including spider mites (Van Houten et al. 2007), whiteflies (Hoogerbrugge et al. 2005; Calvo et al. 2006), and thrips (Van Houten et al. 2005).

As well, Macrolophus bugs have been successfully used in temperate and Mediterranean Europe for augmentative biological control in protected cultivation. Although mainly marketed for controlling whitefly pests, they are polyphagous and also feed on several other arthropod pests. Macrolophus caliginosus Wagner (Heteroptera: Miridae) has proven to be effective in controlling many insect pests of greenhouse vegetables (Kortam et al. 2014).

The present study aimed to evaluate the efficacy of $O$. albidipennis compared to other biocontrol agents and also to chemical application for controlling T. urticae on sweet pepper under greenhouse conditions in Egypt.

\section{Materials and methods}

The hangable cards of $A$. swirskii were provided by the INRA Research Center in Sophia Antipolis, France, within the framework of the Imhotep project "Characterization and modeling of microclimatic heterogeneity at the plant level, in relation to the repartition of biocontrol agents (Neoseiulus cucumeris and A. swirskii) used to control thrips and red spider mites on greenhouse crops". O. albidipennis and M. caliginosus have been reared at "Chrysopa mass rearing unit" at the Faculty of Agriculture, Cairo University, Giza, Egypt.

\section{Rearing of Orius albidipennis}

Adults of $O$. albidipennis were placed in jars $(12 \mathrm{~cm}$ in height and $7 \mathrm{~cm}$ in diameter) and provided with fresh bean pods (Phaseolus vulgaris) for oviposition. Ephestia kuehniella eggs were introduced as a food source. The pods were collected daily and placed in boxes measuring $(16 \mathrm{~L} \times 25 \mathrm{~W} \times 11 \mathrm{H}(\mathrm{cm}))$ until hatching for nymphal rearing. After hatching, E. kuehniella eggs were also used as a food source for nymphal rearing. The rearing of $O$. albidipennis was carried out in a controlled climatic room at a temperature of $24.3 \pm 0.2{ }^{\circ} \mathrm{C}$, photoperiod of $16 \mathrm{~h}$ lighting per day, and a RH of $58.0 \pm 0.5 \%$.

\section{Rearing of Macrolophus caliginosus}

Rearing was carried out in Plexiglass cages $(45 \mathrm{~L} \times 45 \mathrm{~W} \times$ $45 \mathrm{H} \mathrm{cm})$ kept at constant environmental conditions $(25 \pm$
$1{ }^{\circ} \mathrm{C}, 70 \pm 10 \% \mathrm{RH}$ and LD 16:8 photoperiod). Adults and nymphs of the predator were fed on UV-irradiated $E$. kuehniella eggs. Potato seedlings were used for egg laying: females deposited their eggs in the veins and the stakes of the leaf blade.

\section{Experiments on sweet pepper crops grown in a greenhouse}

This study was carried out in a (4.5 m high) commercial greenhouse of $14,040 \mathrm{~m}^{2}\left(180 \mathrm{~L} \times 78 \mathrm{~W} \mathrm{~m}^{2}\right)$ located at Berkash (Giza, Egypt), during the fall-winter pepper plantation of the growing season, 2015-2016. Within this greenhouse, four $320 \mathrm{~m}^{2}$ tunnels $(40 \mathrm{~L} \times 8 \mathrm{~W} \mathrm{~m}$ ) were designed by installing plastic partitions and hermetically fixed to the greenhouse structure; this allowed the isolation of the tunnels from each other and avoided insects to pass from one tunnel to another.

Each tunnel, which was considered as a replicate, included four rows of 90 sweet pepper plants (Capsicum annuum L.) of the variety Helenscy (a total of 360 plants/tunnel). Fifteen-centimeter high sweet pepper plants were transplanted directly in the soil during the late summer (the 3rd week of August). The agronomic practices were carried out by farmers. Insecticide applications and plant pruning were strictly avoided during the experimentations. Three fungicide applications (commercial formulations: Acrobat/Copper 46\% WP, Basf, Egypt; with application rate of $150 \mathrm{~g} \mathrm{~h}^{-1}$ ) were carried out at 20-day intervals during November.

An air temperature and relative humidity sensor (SEN-R Combisensor Temp/RH Adcon) was connected to a solar-powered data logger (A723 addIT, ADCON, Klosterneuburg, Austria). It was installed $1.5 \mathrm{~m}$ above the ground, in the central tunnel. Hygro-thermal data were recorded every $30 \mathrm{~min}$ throughout the experiment.

\section{Releases of the different predators and samplings}

Four previously described tunnels were used as follows: the first one for releasing $A$. swirskii at a rate of 2 adults $/ \mathrm{m}^{2}$, the second one for releasing $O$. albidipennis at a rate of $1 / 2 / \mathrm{m}^{2}$, the third tunnel for $M$. caliginosus being released at a rate of 1 adult $/ \mathrm{m}^{2}$ (release dose of $M$. caliginosus was chosen according to Koskula et al. (1999)), while the fourth one remained untreated as a control. Nine releases were carried out during the season, at 10-15-day intervals, starting from December 2015 till March 2016. A total of 120 plants (30 plants/ treatment) was chosen. Randomized samples of five leaflets/each plant were taken at 10-15-day intervals. Counts of moving stages of $T$. urticae were estimated in the field using a special magnifying hand lens $(\times 10)$.

Sweet pepper production yield was estimated for each treatment after releasing the three predators during winter plantation of 2015-2016 and 2016-2017. 
A cost-benefit economical evaluation of the results, when applying the three released predators on the greenhouse sweet peppers to control $T$. urticae, was carried out. Cost benefits were calculated as follows (Goda et al. 2015):

Cost benefits $=$ costs of yield production-control costs

In the second season of plantation (2016-2017), the efficiency of $O$. albidipennis was compared to that of three recommended pesticides. Ten releases of the insect predator $O$. albidipennis, at the rate of $1 / 2 / \mathrm{m}^{2}$, were conducted during the season in a parallel experiment, using the three pesticides, Vertimec (abamectin), Kanemite (acequinocyl), and Agremic (abamectin), 12 times at the recommended dose (Table 1).

\section{Statistical analysis}

A randomized complete block design with two factors was used for analysis of all data with 30 replications for each parameter. The treatment means were compared by least significant difference (LSD) test as given by Snedecor and Cochran (1976) using Assistant program.

\section{Results and discussion}

In the early releases of the three investigated predators on the sweet pepper plants, the two-spotted spider mite populations were at their lowest density on the day of the predator release (Fig. 1). There were 3.5 motile stages/leaflet among the experimental tunnels. After the date of released predators, T. urticae populations slightly increased on sweet pepper plants received $O$. albidipennis and $A$. swirskii to reach their high density at February 16, 2016 (the 7th release of predators). There were 6.14 and 5.94 motile stages/leaflet in tunnels released with $O$. albidipennis and A. swirskii, respectively. Then, the mite populations slightly decreased in the previous tunnels to reach 2.8 and 2 motile stages/leaflet in the two released tunnels, respectively. However, these levels of mite infestation are known to be less injurious to plants and are considered within the economic threshold level (Warabieda 2015). For M. caliginosus released on the sweet pepper plants, similar trends of the two-spotted spider mite populations were observed until February 16, 2016 (the 7th week of predator release); then, that of the mite gradually increased to reach its maximum counts of 12.56 motile stages/leaflet on March 27, 2017. On the other hand, $T$. urticae populations increased gradually on sweet pepper plants in the control (untreated plants) tunnels. Then, the mite population increased rapidly to reach its maximum counts, i.e., 40.93 motile stages/ leaflet on March 27, 2017.

Analysis of results showed that the time $(F=35.91$; $P<0.0001)$ and type of released predators $(F=183.24$; $\mathrm{P}<0.0001)$ significantly affected the number of mites. The interaction treatment-date was also significant $F=12.62$; $P<0.0001$. All used predators (O. albidipennis, M. caliginosus, and $A$. swirskii) effectively reduced the number of $T$. urticae on sweet pepper plants. On March 27, 2016, the mean numbers of the two-spotted spider mite in all released tunnels were significantly lower than those in the control treatment (Fig. 1). The differences among treatments were highly significant $F=204.283 ; P<0.0001$.

\section{A. swirskii treatment}

Obtained results revealed that it is possible to reduce the number of $T$. urticae by applying biocontrol agents. In particular, the best results were obtained in the tunnels when the mite predator $A$. swirskii was released. The mean number of mites observed at A. swirskii

Table 1 A list of pesticide application used to control T. urticae on sweet pepper in greenhouse using a chemical treatment during winter plantation of $2016-2017$

\begin{tabular}{llll}
\hline Date & Trade name & Active ingredient & Rates of application $\left(\mathrm{cm}^{3} / \mathrm{L}\right)$ \\
\hline $21 / 11 / 2016$ & Vertimec $1.8 \%$ & Abamectin & $200 \mathrm{~cm}^{3} / 200 \mathrm{~L}$ \\
$05 / 12 / 2016$ & Kanemite $15 \% \mathrm{Sc}$ & Acequinocyl & $200 \mathrm{~cm}^{3} / 200 \mathrm{~L}$ \\
$25 / 12 / 2016$ & Vertimec $1.8 \%$ & Abamectin & $200 \mathrm{~cm}^{3} / 200 \mathrm{~L}$ \\
$16 / 01 / 2017$ & Vertimec $1.8 \%$ & Abamectin & $200 \mathrm{~cm}^{3} / 200 \mathrm{~L}$ \\
$25 / 01 / 2017$ & Vertimec $1.8 \%$ & Abamectin & $200 \mathrm{~cm}^{3} / 200 \mathrm{~L}$ \\
$05 / 02 / 2017$ & Agremic $8.4 \% S C$ & Abamectin & $40 \mathrm{~cm}^{3} / 200 \mathrm{~L}$ \\
$12 / 02 / 2017$ & Vertimec $1.8 \%$ & Abamectin & $200 \mathrm{~cm}^{3} / 200 \mathrm{~L}$ \\
$22 / 02 / 2017$ & Kanemite $15 \% \mathrm{Sc}$ & Acequinocyl & $175 \mathrm{~cm}^{3} / 200 \mathrm{~L}$ \\
$28 / 02 / 2017$ & Vertimec $1.8 \%$ & Abamectin & $200 \mathrm{~cm}^{3} / 200 \mathrm{~L}$ \\
$05 / 03 / 2017$ & Vertimec $1.8 \%$ & Abamectin & $200 \mathrm{~cm}^{3} / 200 \mathrm{~L}$ \\
$10 / 03 / 2017$ & Kanemite $15 \% \mathrm{Sc}$ & Acequinocyl & $175 \mathrm{~cm}^{3} / 200 \mathrm{~L}$ \\
$17 / 03 / 2017$ & Vertimec $1.8 \%$ & Abamectin & $200 \mathrm{~cm}^{3} / 200 \mathrm{~L}$ \\
\hline
\end{tabular}




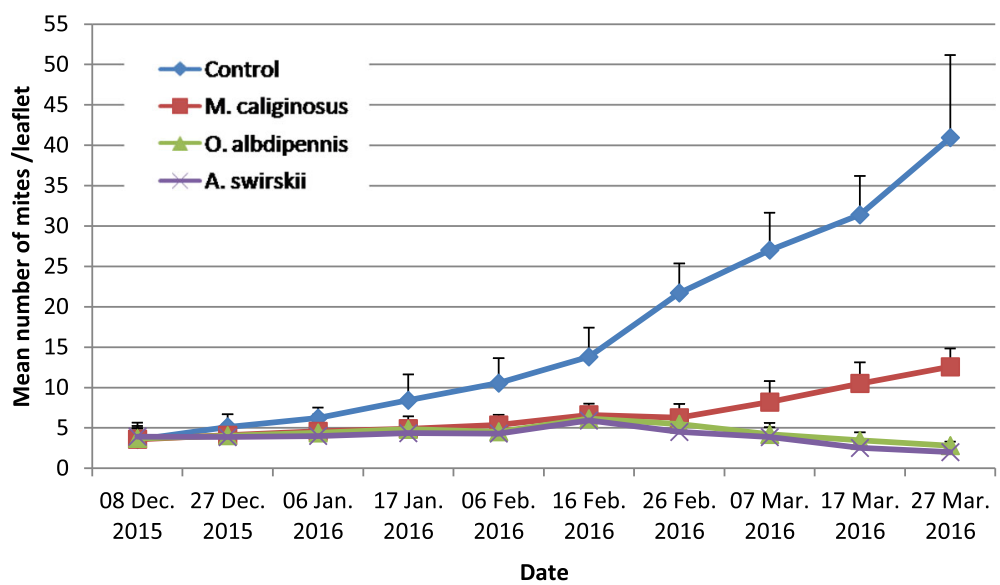

Fig. 1 Mean numbers of T. urticae/leaflet after releasing three different predators (O. albidipennis, M. caliginosus, and A. swirskii) on the sweet pepper in the greenhouse during the winter plantation of 2015-2016

treatments ( 2 mites/leaflet) remained lower than when releasing O. albidipennis and M. caliginosus (2.8 and 12 . 56 mites/leaflet, respectively).However, there was a significant difference between $O$. albidipennis and $M$. caliginosus $(F=222.377 ; P<0.0001)$. These results were in agreement with Tomczyk and Andryka (2016) who observed that A. swirskii played a significant role in controlling populations of $T$. urticae.

\section{O. albidipennis treatment}

O. albidipennis proved to be highly efficient in controlling T. urticae on sweet pepper under greenhouse conditions. Mean number of T. urticae with O. albidipennis (2.8 mites/leaflet) was lower than with $M$. caliginosus (12.56 mites/leaflet) with a significant difference between both of their treatments $(F=154.308 ; P<0.0001)$. However, insignificant difference between $O$. albidipennis and A. swirskii could be observed. Fathi (2014) reported that using Orius minutus led to effective and more sustainable management of $T$. urticae in potato fields.

\section{M. caliginosus treatment}

There was a significant difference between each of $M$. caliginosus, O. albidipennis, and A. swirskii treatments. The highest mean number of $T$. urticae after control treatment was recorded in $M$. caliginosus treatment (12. 56 mites/leaflet), whereas it dropped to 2.8 and 2 mites/ leaflet in the case of revealed $O$. albidipennis and $A$. swirskii, respectively. Moreover, it was of interest to mention that a high predation rate of $M$. caliginosus to T. urticae was obtained in the absence of greenhouse whitefly larvae (Veire et al. 2002).

The results of the present study showed the efficacy of $O$. albidipennis and $A$. swirskii in minimizing the damage levels of $T$. urticae, keeping thus the population density under an acceptable threshold, when compared to the untreated control plants.

\section{Estimation of sweet pepper yield after releasing the three predators during winter plantation of 2015-2016}

Production yield, in the experimental tunnels of the sweet pepper, was recorded during the winter plantation of 2015-2016. Sweet pepper plants protected by releasing A. swirskii yielded $881.22 \mathrm{~kg}$, followed by those protected by $O$. albidipennis and $M$. caliginosus which produced 870.52 and $842.35 \mathrm{~kg}$, respectively (Table 2), whereas it dropped to $685.2 \mathrm{~kg}$ in the unprotected plants, on which no predators were released. The obtained results showed that the production yield of sweet pepper in tunnels increased between 26 and $24 \%$ after releasing $A$. swirskii and O. albidipennis, respectively, as compared to control. These results confirm those obtained by Adly (2015) who reported that there was

Table 2 Total production yield, bioagent costs, and cost benefits of sweet pepper when releasing the three predators, 0 . albidipennis, M. caliginosus, and A. swirskii, in the experimental tunnels during winter plantation of 2015-2016

\begin{tabular}{lllll}
\hline Treatments & Yield $(\mathrm{kg})$ & Production price $(\mathrm{LE})$ & Bioagent costs (LE) & Cost benefits (LE) \\
\hline Control & 685.2 & 8565 & - & 8565 \\
O. albidipennis & 870.52 & $10,881.5$ & 129.6 & $10,751.9$ \\
M. caliginosus & 842.35 & $10,529.375$ & 259.2 & $10,270.175$ \\
A. swirskii & 881.22 & $11,015.25$ & 345.6 & $10,669.65$ \\
\hline
\end{tabular}




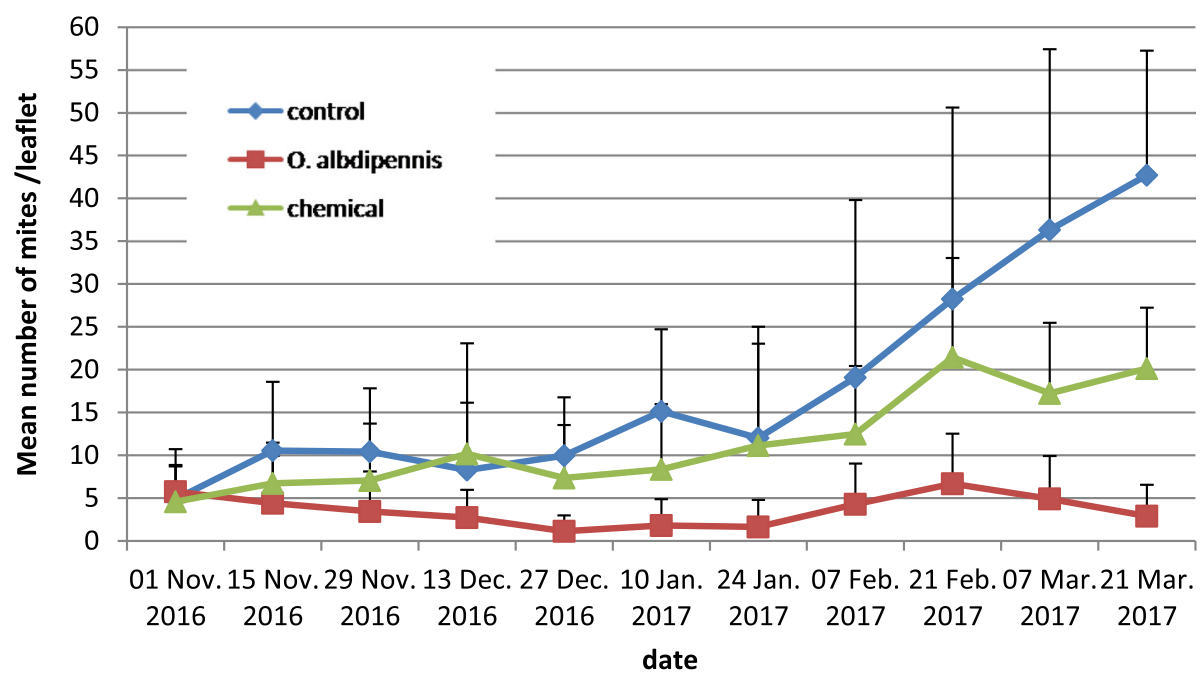

Fig. 2 Mean numbers of T. urticae/leaflet when controlled by two different (releasing predators and chemical pesticides) methods in a sweet pepper greenhouse during the winter plantation of 2016-2017

$40 \%$ increase in pepper yield by using the mite predator as one of the biocontrol agents for controlling T. urticae.

\section{Cost benefits when releasing the three predators of $O$. albidipennis, $M$. caliginosus, and A. swirskii}

Data shown in Table 2 presented the cost benefits of each predator treatment. Releasing of $O$. albidipennis resulted in high cost benefits $(10,751.9 \mathrm{LE})$ where the total cost of releasing $O$. albidipennis throughout the whole growing season attained is $129 \mathrm{LE}$, while that of M. caliginosus recorded the lowest cost benefit (10,270.175 LE). The cost benefits of $O$. albidipennis, $M$. caliginosus, and A. swirskii were more than control by $25.53,15.85$, and $20.49 \%$, respectively.

The results showed the efficacy of O. albidipennis and A. swirskii in eliminating the damage levels of T. urticae and thus keeping the population density under an acceptable economic threshold.

\section{Season 2016-2017}

Figure 2 presents the mean number of $T$. urticae/leaflet for the three treatments. Analysis of treatment factors showed a high significant difference between these treatments $(F=130.224 ; P<0.0001)$. Obtained results revealed that applying $O$. albidipennis proved to be efficient in controlling T. urticae on sweet pepper, with the lowest number of $T$. urticae recorded (2.9 mites/leaflet). However, with chemical control, the mean number of $T$. urticae varied from 12.48 mites/leaflet on the 7 th of February to 20.13 mites/leaflet on the 21st of March (the end of the season). Moreover, development for resistance was observed in the T. urticae population, after application of pesticides (Hussey 1985).

Our strategy to control T. urticae achieved a good result since the pest population density could be kept below the economic threshold which has been estimated to be three motile forms per leaf (Warabieda 2015).

\section{Estimation of sweet pepper yield after releasing 0 . albidipennis during winter plantation of 2016-2017}

The highest yield production of sweet pepper $(864.57 \mathrm{~kg}$ with a $31.36 \%$ increase) was recorded during the winter plantation in 2016-2017 when releasing O. albidipennis, when compared to that of the control, followed by that of the chemical treatment $(754.7 \mathrm{~kg})$ which represented $12.7 \%$ reduction in production yield, compared to that of $O$. albidipennis treatment. High population density of T. urticae in chemical treatment played a significant role in reduction of sweet pepper yield. Our results agree with those obtained by Edwards (1986) who found $60-80 \%$ reduction in yield by using pesticides to control spider mites and $23 \%$ increase in crop yield

Table 3 Total yield production, bioagent costs, and cost benefits of sweet pepper with release of O. albidipennis compared to chemical applications in the experimental tunnels during winter plantation of 2016-2017

\begin{tabular}{lllll}
\hline Treatments & Yield/treatment $(\mathrm{kg})$ & Production price (LE) & Bioagent costs (LE) & Cost benefits (LE) \\
\hline Control & 593.36 & 7417 & - & 7417 \\
O. albidipennis & 864.57 & $10,807.125$ & 144 & $10,663.125$ \\
Chemical & 754.7 & 9433.75 & 674.9 & 8758.85 \\
\hline
\end{tabular}


in the case of biological control treatments in tomato and cucumber greenhouses.

\section{Cost benefits in releasing $O$. albidipennis compared to applying chemical pesticides}

The cost for all agricultural practices was equal in all experimental tunnels, except for the cost of T. urticae control. Ten releases of $O$. albidipennis throughout the whole growing season were attained (144 LE), which resulted the highest cost benefits (Table 3). The cost benefits of $\mathrm{O}$. albidipennis treatment were more than those of the control by $43.67 \%$. Twelve applications of recommended pesticides amounted to $674.9 \mathrm{LE}$.

\section{Conclusions}

In conclusion, $T$. urticae was able to cause significant damage to sweet pepper crop. Biological control using the insect predator $O$. albidipennis was the most effective method to control T. urticae under greenhouse conditions. On the one hand, it resulted in $31.36 \%$ increase in yield, and on the other hand, it could reduce the chemical application which would improve the food safety and reduce the environmental pollution.

\section{Acknowledgements}

Thanks are due to Technogreen farming company, especially to Engr Mohamed Kamal who offered the opportunity to carry out the present assay in the farm greenhouse.

\section{Authors' contributions}

Field Application was carried out by MNK. SAEA performed the design of the study. SAEA, AIA and $I H H$ revised the manuscript. All authors read and approved the final manuscript.

\section{Competing interests}

The authors declare that they have no competing interests.

\section{Publisher's Note}

Springer Nature remains neutral with regard to jurisdictional claims in published maps and institutional affiliations.

\section{Author details}

${ }^{1}$ Department of Economic Entomology and Pesticides, Chrysopa Mass Production Laboratory, Faculty of Agriculture, Cairo University, Giza, Egypt ${ }^{2}$ Central Laboratory of Organic Agriculture, Agric. Res. Center, Giza, Egypt.

Received: 22 June 2017 Accepted: 26 March 2018

Published online: 03 May 2018

\section{References}

Adly D (2015) Comparative study of biological and chemical control programs of certain cucumber pests in greenhouses. Proceeding of 4th International Conference, ESPCP2015, Cairo, Egypt, 19-22 October Egypt. Egypt J Biol Pest Control 25(3):691-696

Al-Kherb WA (2013) Biological characteristics of Orius albidipennis (Hemiptera: Anthocoridae) reared on insect and mite preys. Int J Agric Res 9(2):110-118

Calvo J, Fernandez P, Bolckmans K, Belda JE (2006) Amblyseius swirskii (Acari: Phytoseiidae) as a biological control agent of the tobacco whitefly Bemisia tabaci (Horn. : Aleyrodidae) in protected sweet pepper crops in Southern Spain. IOBC/ WPRS Bulletin 29(4):77-82

Edwards CA (1986) Agrochemicals as environmental pollutants. In: Van Hofsten B, Eckstrom $\mathrm{G}$ (eds) Control of pesticide applications and residues in food. A guide and directory. Swedish Science Press, Uppsala
El-Laithy AYM, Elseedy EMA, El-Kholi MY, Abou-Ellela MM, Svobodova Z (2013) Population dynamics of major insect and mite pests and control on sweet pepper grown in net house in Egypt. Integrated control of plant mites. IOBC WPRS Bulletin 93:31-38

Fathi SAA (2014) Efficiency of Orius minutus for control of Tetranychus urticae on selected potato cultivars. Biocont Sci and Technol 24(8):936-949

Fatnassi H, El Arnaouty SA, Brun R, Pizzol J, Kortam M, Métay C, Poncet C (2015) Dispersal and maintenance of Neoseiulus cucumeris Oudemans and Amblyseius swirskii (Acari: Phytoseiidae) to control thrips in greenhouse crops as influenced by micro habitat environment. Proceeding of 4th International Conference, ESPCP2015, Cairo, Egypt, 19-22 October Egypt. Egypt J Biol Pest Control 25(3):703-707

Ginette YA, Simon F, Serge K, Komi KM, Fiaboe S, Subramanian M, Thibaud M (2014) Dispersal behavior of Tetranychus evansi and T. urticae on tomato at several spatial scales and densities: implications for integrated pest management. PLoS One 9(4):e950

Goda NF, El-Heneidy AH, Djelouah K, Hassan N (2015) Integrated pest management of the tomato leaf miner, Tuta absoluta (Meyrick) (Lepidoptera: Gelechiidae) in tomato fields in Egypt. Proceeding of 4th International Conference, ESPCP2015, Cairo, Egypt, 19-22 October Egypt. Egypt J Biol Pest Control 25(3):655-661

Heikal IH, Ebrahim AA (2013) Biological control of Tetranychus urticae Koch on sweet pepper plantation in a commercial farm by the predatory mite Phytoseiulus macropilis (Banks). Egyptian J Agric Res 91(3):1161-1171

Hoogerbrugge H, Calvo J, van Houten YM, Belda JE, Bolckmans K (2005) Biological control of the tobacco whitefly Bemisia tabaci with the predatory mite Amblyseius swirskii in sweet pepper crops. IOBC WPRS Bulletin 28(1): 119-122

Hussey NW (1985) History of biological control in protected culture. In: Hussey NW, Scopes N (eds) Biological pest control. The glasshouse experience. Blandford press, Dorset, pp 11-22 175-179

Kortam MN, El Arnaouty SA, Afifi Al, Heikal IH (2014) Efficacy of different biological control methods for controlling the tomato leaf miner, Tuta absoluta (Meyrick) (Lepidoptera: Gelechiidae) on tomato in greenhouse in Egypt. Egypt J Biol Pest Control 24(2):523-528

Koskula H, Vaenninen I, Lindqvist I (1999) The role of Macrolophus caliginosus (Heteroptera: Miridae) in controlling the two-spotted mite in greenhouse tomato under North-European conditions. Bulletin OILB/SROP 22(1):129-132

Snedecor GA, Cochran WG (1976) Statistical method. lowa State Univ. Press, Ames

Tehri K, Gulati R, Geroh M (2014) Damage potential of Tetranychus urticae Koch to cucumber fruit and foliage: effect of initial infestation density. J Appl Nat Sci (JANS) 6(1):170-176

Tomczyk A, Andryka P (2016) Effectiveness of Swirski-mite (Amblyseius swirskii Athias-Henriot) in control of two-spotted spider mite (Tetranychus urticae Koch) on cucumber plants treated with biostimulants. Prog Plant Prot 56(2):175-179

Van Houten YM, Hoogerbrugge H, Bolckmans KJ (2007) Spider mite control by four phytoseiid species with different degrees of polyphagy. IOBC WPRS Bulletin 30(5):123-127

Van Houten YM, Østlie ML, Hoogerbrugge H, Bolckmans K (2005) Biological control of western flower thrips on sweet pepper using the predatory mites Amblyseius cucumeris, Iphiseius degenerans, A. andersoni and A. swirskii. IOBC WPRS Bulletin 28(1):283-286

Veire M, Cornelis E, Tirry L (2002) Can Tetranychus urticae be controlled by Macrolophus caliginosus in glasshouse tomatoes? OILB/SROP Bulletin 25(1):265-268

Warabieda W (2015) Effect of two-spotted spider mite population (Tetranychus urticae Koch) on growth parameters and yield of the summer apple cv. Katja. Hort Sci (Prague) 42(4):167-175

Xie L, Miao H, Xiao-Yue Hong XY (2006) The two spotted spider mite Tetranychus urticae Koch and the carmine spider mite Tetranychusc innabarinus (Boisduval) in China mixed in their Wolbachia phylogenetic tree. Zootaxa 1166:33-46 